
doktorantka w Zakładzie Tekstologii i Gramatyki Współcze-

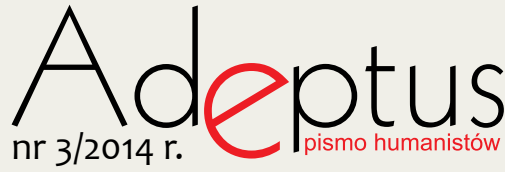
snego Języka Polskiego UMCS. W ramach programu MNiSW „Diamentowy Grant” realizuje projekt Językowo-kulturowy obraz zwierząt domowych w języku potocznym i polskiej kulturze ludowej, rekonstruując ludowe wyobrażenia zwierząt domowych. Jej zainteresowania naukowe sytuują się w ramach etnolingwistyki kognitywnej skupionej wokół problematyki językowego obrazu i powiązanej z badaniami lubelskich etnolingwistów pracujących nad Słownikiem stereotypów i symboli ludowych

\title{
Olga Kielak
}

\section{Symbolika leszczyny \\ w polskiej kulturze ludowej. Fragment definicji kognitywnej}

$\mathrm{N}$ iemiecki badacz symboli, Manfred Lurker, pisał: „,podstawowa prawda rzeczywistości brzmi, że żadna rzecz nie jest jedynie sobą" (Lurker, 2011, s. 13), rzecz zawierać ma w sobie coś więcej, niż ona sama, sens uzyskując dopiero wówczas, gdy człowiek uświadomi sobie, że odsyła do czegoś większego (Lurker, 2011, s. 13). W rozważaniach nad problemem istoty i znaczenia symbolu Lurker doszedł do wniosku, że znaczy on „nie tylko odsyłając do znaczenia czegoś innego, lecz także uprzytamniając, reprezentując jego znaczenie, w pewnym sensie mając w owym znaczeniu udział. $Z$ tego wynika, że nie można po prostu wymyślać lub projektować symboli; są one dane i zakorzenione w praprzyczynie ludzkiego doświadczenia zbiorowego" (Lurker, 2011, s. 28).

Zakorzenione w ludzkim myśleniu symbole rekonstruują autorzy lubelskiego słownika etnolingwistycznego. Jerzy Bartmiński we wstępie do Słownika stereotypów i symboli ludowych (SSiSL, 1996) definiował symbol jako „takie wyobrażenie przedmiotu, które jest traktowane jako reprezentant innego wyobrażenia w ramach większego układu znaków" (Bartmiński, 1996, s. 9). Autorzy słownika ujmują symbolikę w podwójnej relacji: „,czego” symbolem jest przedmiot hasłowy oraz „,co” jest symbolem przedmiotu hasłowego. 
W przypadku leszczynowego krzewu, warstwa symboliczna jest wyjątkowo bogata, o czym przekonałam się, rekonstruując na potrzeby mojej pracy magisterskiej językowokulturowe wyobrażenia wybranych krzewów w języku potocznym i polskiej kulturze ludowej".

Symboliczne sensy, związane z leszczyną, ujawniają dawny sposób postrzegania tego krzewu przez mieszkańców wsi. W tekstach folkloru na gałęziach rosnącej w lesie leszczyny śpiewają ptaki, pod jej korzeniami drzemie król wężów; leszczynowy krzew jest świadkiem miłości chłopaka i dziewczyny, obserwuje ich zaloty, mimowolnie przysłuchuje się rozstaniu, wtóruje w płaczu dziewczynie. Leszczynowe gałęzie zatknięte na polu nie tylko zabezpieczały przed piorunami, ale i zapewniały urodzaj; dodane do pierwszych kąpieli dziecka chroniły je przed chorobami w przyszłości.

Narzędziem badawczym, którym się posługuję, jest definicja kognitywna, zaproponowana w 1988 roku przez Jerzego Bartmińskiego, a w sposób systematyczny wykorzystywana przez autorów lubelskiego etnolingwistycznego Słownika stereotypów i symboli ludowych (dalej zwane SSiSL). Definicja ta „,za cel główny przyjmuje zdanie sprawy ze sposobu pojmowania przedmiotu przez mówiących danym językiem, tj. ze sposobu utrwalonej społecznie i dającej się poznać poprzez język i użycie języka wiedzy o świecie, kategoryzacji jego zjawisk, ich charakterystyki i wartościowania" (Bartmiński, 1988, s. 169-170).

Definicja kognitywna, odpowiadająca nie tyle na pytanie „co oznacza X”, ile na pytanie: ,jak ludzie rozumieją X”, obejmuje cechy typowego przedmiotu, składające się na nią stereotypowe sądy są ułożone na zasadzie koniunkcji cech w przykładowe kategorie semantyczne. Taka budowa definicji sprawia, że jest ona znacznie bardziej rozbudowana niż klasyczna definicja taksonomiczna, w skład której wchodzą genus proximum (określający wstępną kategoryzację i przypisujący przedmiot do jakiejś nadrzędnej kategorii) oraz differentia specifica (będąca zbiorem cech koniecznych i wystarczających). Posiadająca charakter poznawczy (łac. cognosco 'poznaję'), w przeciwieństwie do scjentystycznej definicji taksonomicznej, w objaśnieniach operuje elementami wiedzy potocznej, rezygnując z terminologii naukowej (Bartmiński, 1988, s. 177). Konsekwencją przyjęcia takiego sposobu opisu przedmiotu jest odpowiedni dobór podstawy materiałowej, w skład której powinny wejść dane systemowe, zapisy tekstów badanego języka, wywiady z informatorami-użytkownikami oraz materiały socjologiczne i etnograficzne, dotyczące „,sposobu zastosowania danego przedmiotu

\footnotetext{
${ }^{1}$ Definicje kognitywne wybranych krzewów, w tym definicja leszczyny, zostały zamieszczone w pracy magisterskiej Językowokulturowy obraz krzewów w polszczyźnie potocznej i ludowej, napisanej pod kierunkiem prof. dr hab. S. Niebrzegowskiej-Bartmińskiej; zob. (Kielak, 2013).
} 
w kulturze i zachowań kulturowych użytkowników języka wobec przedmiotu” (Bartmiński, 1988, s. 177).

Podstawą materiałową dla rekonstrukcji wyobrażenia leszczyny były dane dialektologiczne, folklorystyczne (różne gatunki tekstów, m.in.: przysłowia, zamówienia, zaklęcia, pieśni, baśnie, legendy i podania) i etnograficzne (tj. zapisy wierzeń i opisy praktyk). W analizach wykorzystałam dane językowe ze słowników języka polskiego, słowników i atlasów gwarowych, słowników etymologicznych, konteksty wyekscerpowane z materiałów XIX-i XX-wiecznych, a także materiały terenowe - zarówno zebrane samodzielnie, jak i zarchiwizowane w Pracowni „Archiwum Etnolingwistyczne UMCS”.

Zgromadzony materiał pozwolił wyróżnić następujące segmenty opisu leszczyny: nazwy, hiperonim, kolekcje i kompleksy, opozycje oraz takie kategorie (fasety), jak: pochodzenie, wygląd, części, cechy niezwiązane z wyglądem, wiek, czas kwitnienia, miejsce, lokalizator, czynności i stany, rozmówca, obiekt, zastosowanie (apotropeiczne, magiczne, lecznicze, obrzędowe i praktyczne), przepowiednie, wróżby, ekwiwalencje oraz symbolikę, co jest zgodne z zasadą przyjętą w SSiSL.

W artykule omówiona została symbolika leszczyny stanowiąca z jednej strony zaledwie wycinek (jedną fasetę definicji kognitywnej leszczynowego krzewu), z drugiej - będąca kategorią, która wieńczy hasło, bazując na pozostałych charakterystykach z pozostałych faset, spina je wspólną klamrą.

\section{Symbolika drzewa kosmicznego}

Analiza zebranego materiału pozwala upatrywać w leszczynie symbol drzewa kosmicznego, drzewa życia. Wedle wierzeń, w drzewie kosmicznym można było wydzielić trzy części, z każdą zaś z nich miał być związany inny rodzaj istot, najczęściej zwierząt. Z górną częścią drzewa wiązano ptaki, z częścią środkową - zwierzęta kopytne (m.in. jelenie, łosie, krowy, konie i antylopy) oraz człowieka, z częścią podziemną, korzeniami - wiązano węże, żaby, myszy, bobry, wydry, ryby, czasami nawet niedźwiedzie i fantastyczne potwory [Mif Tok 1/40o]. Odwołaniem do symboliki drzewa życia jest obecność w górnej części leszczyny ptaków, w środkowej - ludzi i zwierząt, pod jej korzeniami zaś - króla wężów.

Leszczyna jest krzewem, na którego gałęziach chętnie siadają ptaki - do ptasich bywalców leszczynowego krzewu zalicza się: słowika [ZWAK 1892/138, podob.: Bart PANLub 4/426], sikorkę i ziębę [ZWAK 1892/138], dudka [K 6 Krak 392-393], sokoła [K 6 Krak 36] oraz kukułkę [Płat Krak 364, podob.: Stoin Żyw 455, Gaw Król 32-33, ZWAK 1882/319]. 
W pieśniach miłosnych pod/za gęstą leszczyną śpiewa słowiczek: wesoło, gdy siedzi tam także urocza dziewczyna (pod gęstą leszczyną, gdzie słowiczek wesoło śpiewa, tam siedziała urocza dziewczyna, hej, hej, z którą luby rozstawać sie miał [Bart PANLub 4/426]), żałośnie, gdy dziewczyna tam się topi (za gęstą leszczyno, gdzie słowiczek żałośnie śpiewa, tam słowiczek wesoło nie śpiewa, hej, hej, bo dziewczyna utopiła sie [Bart PANLub 4/426]).

Na leszczynie kuka [Płat Krak 364, podob.: Stoin Żyw 455], siedzi [Gaw Król 32-33], znajduje się [ZWAK 1882/319] kukułka. W pieśniach weselnych i miłosnych kukułka - wróżąca w polskim folklorze zamążpójście, ożenek [Wisła 1898/395] - kuka na/po leszczynie: Po gęstej leszczynie kukułeczka kuka, nie mądry ten chłopak, co majątku szuka. [Płat Krak 364], kuka ubogiej dziewczynie: Zakukała w lesie na lescynie zakukała ubogiej dziewcynie, hej, rano, ranusieńko w cas. [Stoin Żyw 455]².

W tekstach pieśniowych pod leszczyną znajdują się/ są pozostawiane konie. W pieśni weselnej cztery konie / siedem koni pod leszczyną - cztery konie / siedem koni pojechały/pojechało do ślubu z dziewczyną [Bart PANLub 2/503]. W zielonej leszczynie chłopak/mężczyzna/pan uwiązuje konie, sam zaś wyrusza na łowy - dziewczyny [K 28 Maz 228, podob.: Płat Krak 134] albo zwierzyny [ZWAK 1885/180] - zanosi dobranoc dziewczynie [K 28 Maz 228], ma zamiar zalecać się do dziewczyny [Płat Krak 134]; konik niewiele wartego chłopaka jest w pieśni uwiązany do suchej leszczyny [ZWAK 1885/180].

W ludowych opowieściach pod korzeniami leszczyny, na której rosła jemioła, mieszkał król wężów [K 17 Lub 148, podob.: Bieg Koleb 106, Wisła 1892/320, 349] - większy od innych przynajmniej dwa razy, ze złotą koroną na głowie, gromadzący wokół siebie pozostałe węże, które wykonywały jego rozkazy [K 17 Lub 148, podob.: Bieg Koleb 106].

Także pochówek pod leszczyną, o którym mowa w pieśniach, jest prawdopodobnie związany z archaicznymi wyobrażeniami o leszczynowym krzewie, będącym odpowiednikiem drzewa kosmicznego, które ułatwi pochowanym pod nim istotom dostanie się do nieba [Mar Drzew 59]. Pod leszczyną usy tuowane są groby/pochowani są ludzie.

W balladach krzew leszczyny wyrasta na mogile wójtowej [K 50 Sa-Kr 245-246], dziewczyny wójtowy [MAAE 1910/203], która zgubiła troje swoich dziatek: A posłał ci wojt po kata, zgubić wojtownę ze świata. Chces li, wojtowna, moją być, chcę cie od śmierci wykupić. Kiem zasłuzyła, niech ginę, bom zawstydziła rodzinę. Wyrosła na nij lescyna: nie płac mie, matko jedyna! [K 50 Sa-Kr 245-246, podob.: MAAE 1910/203]. Leszczyna nie bez przyczyny wyrasta na mogile kobiet, dziewczyn - jest przecież krzewem o żeńskiej charakterystyce; ponadto

\footnotetext{
2 W legendach kukułka, ptak wiązany ze złym sacrum, siedząca na krzewie leszczyny, zdradza kryjówkę Matki Bożej [Gaw Król 32-33], Matki Bożej z Chrystusem [ZWAK 1882/319], za co zostaje ukarana - nie ma własnego gniazda [Gaw Król 32-33, podob.: ZWAK 1882/319] i nie ma gdzie ukrywać swoich piskląt [Gaw Król 32-33].
} 
leszczyna, wyrastająca na mogile, jest symbolicznym przedłużeniem życia pochowanej pod nią zmarłej. Przymiotniki leszczynowy, laskowy są podawane wśród synonimów słowa żywy [DąbGel SS 168] $]^{3}$.

Zmarli pochowani pod leszczyną to osoby, które opuściły ten świat bez dopełnienia obrzędu przejścia, znajdują się, w związku z tym, w stanie ciągłej mediacji - ich śmierć nie została poprzedzona i potwierdzona odpowiednim rytuałem, umarli i zarazem nie umarli - pozostają więc istotami nigdzie nieprzynależącymi - ani do tego, ani do tamtego świata [Stom Antr 159] ${ }^{4}$.

Pod leszczynowym krzewem dochodzi do morderstwa - w pieśni żartobliwej pod leszczyną panny mordują Antka, tutaj także zostaje on pochowany [Bart PANLub 4/671] - w konsekwencji, pod leszczyną dochodzi także do zmiany stanu (pod krzewem żywy staje się umarłym), ale znowu obrzęd przejścia nie zostaje dopełniony, leszczynowy krzew zaś zyskuje właściwości mediacyjne, może pośredniczyć między tym a tamtym światem.

\section{Symbol świętości}

Wedle legend, leszczyna jest krzewem, który zaofiarował schronienie Świętej Rodzinie [Ziół Gaw 161, podob.: Stom Antr 221, Graj Osicz 23-25], Najświęt szej Panience z Dzieciątkiem [Nieb Przes 84, podob.: ZWAK 1883/117, Gaw Król 32-33, Mat NTarg 9, Wisła 1893/108, Etnl 1995 Biłg 165, PSL 1963/2/104], Matce Boskiej [Nieb Przes 114-115, podob.: Etnl 1995 Biłg 166, Nieb Przes 133, Kul Rop 98], uciekającej przed królem Herodem do Egiptu. Za to, że udzieliła schronienia Maryi, leszczyna została nagrodzona - stała się błogosławioną krzewina [Gaw Król 32-33, podob.: PSL 1963/2/104]; krzew ten uważa się za cudowny [Wisła 1893/108], święty [Cisz Sławk 202, podob.: Kul Rop 98], za katolickie drzewo [PSL 1963/2/104], które więcej do powiedzenia ma z praktyk religijnych [Etnl 1994 Czyż 172, Podhale]. O leszczynie mówi się, że jest krzewem Matki Boskiej [Etnl 1995 Biłg 165, podob.: Nieb Przes 133, Bart PANLub 1/457], będącym w łaskach Maryi Panny [Gaw Król 32-33], w który nie biją pioruny. Dzięki obecności sacrum, leszczynowy krzew stał się symbolem świę to ści, osią umożliwiającą człowiekowi nawiązanie kontaktu z niebem. Ponadto legendy o ucieczce Świętej Rodziny do Egiptu stanowią mityczne uzasadnienie cudownej mocy niektórych drzew

\footnotetext{
${ }^{3}$ W tekstach folkloru na zasadzie opozycji życie-śmierć, płodność-bezpłodność przeciwstawione są sobie leszczyna zielona i sucha. Dodatkowo kolor zielony konotuje niedojrzałość i młodość (Libera, 1987, s. 126). Często podkreślana młodość leszczynowego krzewu ma związek z przypisywaną leszczynie witalnością, w pieśniach ludowych krzew kojarzony jest nie z dojrzałą już kobietą, a z młodą, płodną dziewczyną, będącą w pełni sił życiowych (Kielak, 2013).

${ }^{4}$ Miejsce pod drzewem, w tym przypadku pod leszczyną, jest w kulturach tradycyjnych uważane za graniczne - pochowani tu zmarli mogą po śmierci stać się demonami [Mar Drzew 59].
} 
i krzewów [Zow Bib 266]. Rola, którą w owych legendach odegrała leszczyna, tłumaczy, m. in., jej apotropeiczne właściwości ${ }^{5}$.

\section{Symbol życia, trwania, regeneracji i wzrastania}

Leszczyna, krzew co roku rodzący owoce, wyrastający z zasadzonych w ziemi orzechów laskowych [Ziół Gaw 161] jest symbolem życia, trwania, regeneracji, wzrastania [PSL 1990/1/17-18], zapewnia długowieczność [ZWAK 1883/117, podob.: PSL 1990/1/17-18]. W podaniu, zapisanym w Cedzynie, Matuzalem dlatego żył na świecie najdłużej ze wszystkich ludzi, ponieważ zamieszkiwał w budce zrobionej pod krzewem leszczyny [ZWAK 1883/117]. W ludowych opowieściach maść z króla wężów, mieszkającego pod korzeniami krzewu, posiadała właściwości odmładzające [K 17 Lub 148, podob.: Bieg Koleb 106, Wisła 1892/320, 349]. Prawdopodobnie witalność krzewu leszczyny oraz jego związek z odradzającym się życiem były powodem tego, że to właśnie leszczynową pałką zawiadamiano o czyjejś śmierci [Ziół Gaw 160].

Zieleń leszczyny, tak często przywoływana w pieśniach, także aktualizuje regeneracyjną, witalną symbolikę krzewu. Semantyka barwy zielonej, o czym pisał Zbigniew Libera, jest ściśle związana z symboliką drzew i roślinności, z ich żywotnością, zdrowiem i siłą [Libera 1987: 124]. Zieleń ,,zawiera w sobie idee wiecznego trwania bądź wiecznego, okresowego odradzania się” [Libera 1987: 124], to barwa ziemskiej wegetacji i roślinności, kojarzona z rajskim ogrodem i odnową życia, które „,będzie trwało wiecznie” [Libera 1987: 124$]^{6}$.

\section{Symbol mocy i zdrowia}

Wykorzystywana w ludowym lecznictwie leszczyna jest symbolem mocy i zdrowia. Dawniej na leszczynowy krzew ,,przenoszono” febrę [ZWAK 1882/245-246, podob.: MAAE 1910/296, Bieg Lecz 316-318, 328] czy chorobę dziąseł [Bieg Koleb 161, podob.: ZWAK 1884/296-297], wierzono też, że kąpiel w odwarze z leszczyny pomoże oczyścić się kobiecie po połogu,

\footnotetext{
${ }^{5}$ Polskie legendy o ucieczce Świętej Rodziny do Egiptu, a także apotropeiczne zastosowanie leszczynowego krzewu omówione zostały w artykule Dlaczego w leszczynę pioruny nie bijq̨? Polskie wierzenia o leszczynie na tle wierzeń słowiańskich, zob. (Kielak, 2014a).

${ }^{6}$ Z. Libera pisał także o negatywnym znaczeniu zielonej barwy, która symbolizować miała „obcy, leśny i demoniczny świat, przeciwstawiony nierzadko światu swojemu” (Libera, 1987, s. 126), ale to drugie znaczenie zieleni w tym przypadku nie jest aktualizowane.
} 
dzieciom zapewni nie tylko zdrowie i siłę, ale także urodę i powodzenie w miłości, wyleczy również różne choroby. Krzew stosowano także w praktykach uznanych za uzasadnione medycznie, wykorzystując do leczenia różne części rośliny: gałęzie, liście, kwiaty, kwiaty żeńskie - pączki, korę i orzechy (Kielak, 2013).

Giętka, mocna leszczyna, którą niełatwo jest złamać (por. przysłowie Nie gryź z diabłem orzechów, ani leszczyny z nim nie naginaj [NKPP diabeł 115]), służyła do wyrabiania części sprzętów gospodarskich (bron [Kutrz Kurp 2/76], dzierżaków do cepów [Wisła 1889/764], elementów sochy [Kutrz Kurp 2/69]), wędek [Wisła 1903/433], lasek [Kul Wiel 2/662] i rózg [Ziół Gaw 158]. Wedle wierzeń, Pan Bóg stworzył leszczynę dla biedaków: krzew miał podpierać człowieka, gdy nogi odmówią mu już posłuszeństwa [Ziół Gaw 162].

\section{Symbol płodności i obfitości}

Leszczyna, krzew Matki Boskiej (w kulturze ludowej uznawanej za patronkę urodzaju, symbolizującą płodność i macierzyństwo), wydający owoce - orzechy laskowe - jest symbolem płodności i obfitości, wykorzystywanym w magii płodnościowej oraz przy wróżbach dotyczących urodzaju.

Wtykanie leszczynowych gałęzi w pole nie tylko zabezpieczało przed zniszczeniem plonów, ale było też związane z magią płodnościową - miało zapewnić gospodarzowi urodzaj. Kije leszczynowe, służące do poganiania bydła, wkładali pasterze na św. Jana do piérwszego stajania (staja) żyta, aby było piękne [ZWAK 1882/245], aby wyrosło tak wysokie, jak kije z leszczyny [ZWAK 1882/245]. Na środku zasianego pola zatykano także na kijach z leszczyny snopki ze słomy żytniej, bez ziarna [Wisła 1889/878, podob.: Wisła 1893/583]; czyniono to wieczorem, w wigilię Bożego Narodzenia [Wisła 1893/583]. W sposób podobny do snopka, skonstruowane było kropidełko (także sporządzone ze słomy żytniej i leszczynowego kija) [Wisła 1893/583], zatykane przez gospodarza w Wielki Poniedziałek w rogach poświęconego uprzednio zasianego pola ze słowami: Stój sobie z Panem Jezusem i rośnij! [Wisła 1893/583]. Snopki/kropidełka miały sprowadzać urodzaj [Wisła 1889/878, Wisła 1893/583].

Zakwitająca bardzo wcześnie - na przedwiośniu, w lutym, marcu, ewentualnie kwietniu - leszczyna jest krzewem wiązanym z wiosennym początkiem nowego cyklu wegetacyjnego. Aby wymłócone zboże nie psuło się, należało ściąć wiosną zielony kij leszczynowy i po usłyszeniu pierwszego wiosennego grzmotu (będącego symbolicznym „otwarciem ziemi, umożliwiającym jej ujawnienie pełni mocy życiowej” [Tom Drz 35], zapoczątkowują- 
cym cykl wegetacyjny) uczynić tym kijem znak krzyża nad każdą kupą zboża - wówczas można było mieć pewność, że zboże w spichlerzu nie zepsuje się [Wisła 1892/777].

Wieniec dożynkowy, nazywany plonem, uosabiający wszystkie zebrane plony oraz urodzaj, będący ukoronowaniem żniw, udekorowany był, m.in., orzechami z leszczyny [Udz Biec 148-149], wykonany był z gałązek leszczyny z dojrzewającymi orzechami [Ziół Gaw 160]. W zwyczajach żniwiarskich gałąź leszczynowego krzewu, obsypana orzechami, była symbolem obfitości, dowodem błogosławieństwa bożego i dobrą wróżbą na przySzłość [Ziół Gaw 160].

Płodnościowa symbolika leszczyny przejawia się także w obrzędzie gaikowym. Wiosenny zwyczaj obchodzenia wsi z zielonym drzewkiem, zwanym maikiem, gaikiem czy nowym latkiem, badacze wywodzą z przedchrześcijańskiego kultu drzew, zauważając jednocześnie, że demonstracja tego kultu dawała dawniej początek każdemu cyklowi wegetacyjnemu. Gaik był zwykle wykonany ze świerku lub jodełki - po dyngusie chodziły z nim przeważnie dziewczęta, rzadziej chłopcy lub chłopcy i dziewczęta [ŁSE 1963/79]. W Opoczyńskiem gaik był wykonany z czterech prętów leszczynowych, wygiętych w formie kuli przybranej w bibułkowe wstążki, z umieszczonym na jej szczycie krzyżykiem, a nieco niżej - średniej wielkości jabłkiem [ŁSE 1963/79].

\section{Symbol dziewczyny}

W pieśniach ludowych leszczyna jest kojarzona z dziewczyną. Z leszczyną, rosnącą koło młyna, zestawiana jest piękna młynareczka [K 20 Rad 194-195, podob.: Wisła 1896/506]; w pieśniach zalotnych ładna dziewczyna porównywana jest do wysokiej leszczyny: Jak wysoka leszczyna, Mania ładna dziewczyna. [Kot Zn 412], o panieństwie dziewczyny ma świadczyć leszczyna zieleniąca się na jej głowie: Dana jeno, dana, je jeszcze dziewczyna, bo mi się zieleni na głowie leszczyna. [ZWAK 1886/321, podob.: Cisz Sławk 135]; orzechy, owoce leszczynowego krzewu, porównywane są do dziewczęcego wianka: W zielonym gaiku kamyk na kamyku, orzech na leszczynie, wianek na dziewczynie. [Wisła 1904/332]. Leszczyna, symbol dziewczyny, w tekstach pieśniowych często występuje w opozycji do jałowca [Stoin Żyw 455, podob.: Bart PANLub 4/574] i jaworu [Płat Krak 167, podob.: ŁSE 1980/121, Bart PANLub 4/277-278] - drzew męskich.

Leszczyna towarzyszy dziewczynie w ostatnich chwilach jej panieństwa. W pieśniach weselnych pod rosnącą/stojącą na polu / pod lasem / na łące leszczyną rozczesuje włosy, 
żałośnie śpiewa, płacze wychodząca za mąż dziewczyna (pod leszczyną dziewczyna rzęsiste włosy czesała i tak żałośnie śpiewała [Bart PANLub 2/173-174]). Wycinana leszczyna szumi, wtóruje w płaczu wychodzącej za mąż dziewczynie: Szumiała leszczyna, jak ją wycinali, płakała dziewczyna, jak jej ślub dawali. [Płat Krak 401]. Szum, trzask leszczyny jest oznaką smutku i tęsknoty, ujawnia się tu paralelizm między światem przyrody a światem ludzkim, charakterystyczny dla ludowego stylu artystycznego (Bartmiński, 1974, s. 20).

W pieśniach zalotnych i miłosnych oraz w balladach sucha leszczyna symbolizuje pannę, która straciła dziewictwo. Jeden z wariantów pieśni zalotnej brzmi: Kasia nic nie robiła, po sadecku chodziła. Oj i polewała suchą lescyneckę, by się prędko ozwiła. Ozwijaj się lescyna, cóz ja pocnę dziewcyna? Oj utraciłam ruciany wianecek - cóz'em za to nabyła? [K 2 San 144]. Uwiedziona dziewczyna polewa [K 2 San 144], szuka [K 40 MazP 338-339], opatruje [Nieb Przes 55], spogląda [Wisła 1893/147], wygląda [K 40 MazP 340-341] suchej leszczyny, kiedy ta się rozwinie [K 22 Łęcz 125-126], wypuści zielony listek [K 2 San 144, K 40 MazP 521], zakwitnie [K 40 MazP 521, K 22 Łęcz 126] - w pieśniowych formułach niemożliwości dopiero wtedy ma wrócić do niej ukochany [K 2 San 144, podob.: K 40 MazP 338-339, Bart PANLub 4/302, K 22 Łęcz 126]; choć dziewczyna wychodziła nowe trzewiczki, sucha leszczyna jeszcze się nie rozwinęła [Wisła 1893/147] - tak jak sucha leszczyna nie wypuści zielonego listka, tak i dziewczynie nie wróci dziewictwo.

W pieśniach szum leszczynowego krzewu jest często zestawiany z płaczem dziewczyny. W pieśni miłosnej leszczyna (= leszczynowy las) szumi/trzeszczy, gdy jedzie przez nią chłopiec [K 21 Rad 110, podob.: K 40 MazP 282, Bart PANLub 4/444, Nieb Przes 68, ZWAK 1885/238, Wisła 1889/521] - dziewczyna zaś płacze, gdy chłopiec od niej odjeżdżal śmieje się z niej (Jakżem do niej jechał, szumiała leszczyna, jakżem ją odjechał, płakała dziewczyna [Bart PANLub 4/444]; Sumiała lescyna, sumiał gaj, sumiał gaj, płakałaś Marysiu, ja sie śmiał, ja sie śmiał. [ZWAK 1888/196]). W pieśni weselnej krzew szumi - podobnie jak płacze dziewczyna po utracie wianka: Zaszumiała zielona leszczyna, zaszumiałi gaj, zapłakała nadobna dziewczyna, bo jej wianka żal. [Wit Baj 177]. W pieśniach frywolnych leszczyna szumi - dziewczyna płacze, nieusatysfakcjonowana pożyciem małżeńskim: Szumiała leszczyna, płakała dziewczyna. Miała czego płakać: dostała starego, nie chciał na nią skakać. [K 39 Pom 186] $]^{7}$

\footnotetext{
${ }^{7}$ Leszczyna, kojarzona jednocześnie z płodnością, obfitością i dziewczyną, posiada także symbolikę erotyczną. W polskiej kulturze ludowej erotyczne sensy, związane z leszczynowym krzewem, zakodowane są przede wszystkim w pieśniach. Szerzej pisałam o tym w artykule: „Deszczyk pada, rosa siada po drobnej leszczynie...”. Erotyczna symbolika leszczynowego krzewu w ludowych pieśniach mitosnych, (zob. Kielak, 2014b).
} 


\section{Zakończenie}

Myślenie symboliczne, które da się zaobserwować w rekonstrukcji ludowego obrazu leszczyny, opiera się na dwóch podstawowych zasadach: podobieństwa i styczności. W przypadku zasady styczności element symbolizujący jest częścią elementu symbolizowanego, może być atrybutem, materiałem, narzędziem, miejscem, zdarzeniem czy osobą (Niebrzegowska, 1996, s. 80). Z tego powodu leszczyna z ptakami ulokowanymi na jej gałęziach, z wężowym królem u jej korzeni, z ulokowanymi pod krzewem końmi, dziewczyną i mogiłami symbolizuje drzewo kosmiczne. Ponadto, ze względu na ukrywającą się pod nią Świętą Rodzinę, staje się symbolem świętości. W przypadku zasady podobieństwa bazuje się na podobieństwie obserwowanym empirycznie lub opartym na pewnej wiedzy o świecie (Niebrzegowska, 1996, s. 61). W konsekwencji, leszczyna, często charakteryzowana jako zielona, wyrastająca z zasadzonych w ziemi orzechów laskowych - symbolizuje życie, trwanie, witalność; posiadająca orzechy twarde, ciężkie do zgryzienia - moc i zdrowie; wysoka, giętka, rodząca orzechy leszczyna symbolizuje również dziewczynę. Często zasady podobieństwa i styczności łączą się ze sobą w różnych proporcjach, wspólnie decydując o symbolice.

W procesach symbolizacji uaktywniają się wybrane cechy, posiadające potencjał wyzwalania sensów symbolicznych; kojarzenie symboliczne jest zaś operacją intelektualną, która prowadzi do nałożenia lub styczności elementu symbolizującego i symbolizowanego (Niebrzegowska-Bartmińska, 2013, s. 138). Często jednemu elementowi symbolizującemu odpowiada wiele elementów symbolizowanych, z tego też powodu leszczyna może być jednocześnie symbolem drzewa kosmicznego i świętości, życia, trwania, regeneracji i wzrastania, mocy i zdrowia, płodności i obfitości oraz dziewczyny.

Sensy symboliczne, wymagające znajomości kodu kulturowego, po części wydobywane intuicyjnie, zależne od kompetencji badacza, nie są dane wprost, lecz interpretowane. Jak pisze Stanisława Niebrzegowska-Bartmińska (2013, s. 140), ,teksty - zwłaszcza artystyczne, a do nich należą także teksty folkloru - zawierają niezamknięty potencjał semantyczny i pozostają niedopowiedziane, otwarte i podatne na nowe odczytania symboliczne". 


\section{Bibliografia:}

\section{OPRACOWANIA:}

Bartmiński, J. (1974). „Jaś koniki poił”. Uwagi o stylu erotyku ludowego. Teksty, nr 2, s. 11-24. Bartmiński, J. (1988). Definicja kognitywna jako narzędzie opisu konotacji. W: J. Bartmiński (red.), Konotacja (s.169-183). Lublin: Wydawnictwo Uniwersytetu Marii Curie-Skłodowskiej. Bartmiński, J. (1996). O „Słowniku stereotypów i symboli ludowych”. W: J. Bartmiński, S. Niebrzegowska-Bartmińska (red.), Słownik stereotypów i symboli ludowych, t. 1, z. 1, Niebo, światła niebieskie, ogień, kamienie (s.9-34). Lublin: Wydawnictwo Uniwersytetu Marii Curie-Skłodowskiej.

Kielak, O. (2013). Językowo-kulturowy obraz krzewów w polszczyźnie potocznej i ludowej. Praca magisterska napisana pod kierunkiem prof. Stanisławy Niebrzegowskiej-Bartmińskiej w Zakładzie Tekstologii i Gramatyki Współczesnego Języka Polskiego IFP UMCS, Lublin [404 s. mpsu].

Kielak, O. (2014a). Dlaczego w leszczynę pioruny nie biją? Polskie wierzenia o leszczynie na tle wierzeń słowiańskich. W: M. Gaze, K. Kubacka (red.), Bogactwo językowe i kulturowe Europy w oczach Polaków i cudzoziemców, T. 2. Łódź: Wydawnictwo Uniwersytetu Łódzkiego [w druku].

Kielak, O. (2014b). „Deszczyk pada, rosa siada po drobnej leszczynie...” Erotyczna symbolika leszczynowego krzewu w ludowych pieśniach miłosnych. Barbarzyńca. Pismo antropologiczne, nr 1(19), [w druku].

Libera, Z. (1987). Semiotyka barw w polskiej kulturze ludowej i innych kulturach słowiańskich. Etnografia polska, z. 1, s.115-138.

Lurker, M. (2011). Przesłanie symboli w mitach, kulturach i religiach, tłum. R. Wojnakowski. Warszawa: Wydawnictwo Aletheia.

Niebrzegowska, S. (1996). Polski sennik ludowy. Lublin: Wydawnictwo Uniwersytetu Marii Curie-Skłodowskiej.

Niebrzegowska-Bartmińska, S. (2013). Ustalanie znaczeń symbolicznych w słowniku etnolingwistycznym. LingVaria, nr 1 (15), s. 127-144.

\section{SKRÓTY ŹRÓDEŁ:}

Bart PANLub - Polska pieśń i muzyka ludowa. Źródła i materiały. Red. L. Bielawski. Tom 4. Lubelskie. Red. tomu J. Bartmiński. Cz. 1. Pieśni i obrzędy doroczne; Cz. II. Pieśni i obrzędy rodzinne; Cz. III. Pieśni i teksty sytuacyjne; Cz. IV. Pieśni powszechne; Cz. V. Pieśni stanowe i zawodowe, Lublin 2011.

Bieg Koleb - Biegeleisen Henryk, U kolebki. Przed ołtarzem. Nad mogiłą, Lwów 1929.

Bieg Lecz - Biegeleisen Henryk, Lecznictwo ludu polskiego, Kraków 1929.

Cisz Sławk - Ciszewski Stanisław, Lud okolic Sławkowa w powiecie olkuskim, Kraków 1887.

DąbGel SS - Dąbrówka Andrzej, Geller Ewa, Turczyn Ryszard, Słownik synonimów, Warszawa 1996.

Etnl 1994 Czyż - Czyżewski Feliks, Burza w wierzeniach ludowych, „Etnolingwistyka” 4-6, red. Jerzy Bartmiński, Lublin 1994, s. 169-173, [materiał ze wschodniej Lubelszczyzny]. 
Etnl 1995 Biłg - Adamowski Jan, Bartmiński Jerzy, Niebrzegowska Stanisława, Ptaki, zwierzęta i rośliny w relacjach gwarowych z okolic Biłgoraja, „Etnolingwistyka” 7, red. Jerzy Bartmiński, Lublin, 1995, s. 135-178.

Gaw Król - Gawalewicz Maryan, Stachniewicz Piotr, Królowa Niebios. Legendy ludowe o Matce Boskiej, Warszawa 1894.

Graj Osicz - Grajnert Józef, Osiczyna i leszczyna (legenda szlązka), [w:] tegoż, Powiastki i pieśni, Warszawa 1893, s. 22-25.

K

- Kolberg Oskar, Dzieła wszystkie, Wrocław:

K 2 San - T. 2 Sandomierskie, 1962, [wyd. fotoofsetowe z: Lud. Jego zwyczaje, sposób życia, mowa, podania, przysłowia, obrzędy, gasła, zabawy, pieśni, muzyka i tańce. Przedstawił... Serya I [2]..., 1865].

K 6 Krak - T. 6 Krakowskie, cz. 2, 1963, [wyd. fotoofset. z: Lud... Serya VI..., 1873].

K 12 Poz - T.12 W. Ks. Poznańskie, cz. 4, 1963, [wyd. fotoofset. z: Lud... Serya XII..., 1879 ].

K 17 Lub - T. 17 Lubelskie, cz. 2, 1962, [wyd. fotoofset. z: Lud... Serya XVII..., 1884].

K 20 Rad - - T. 20 Radomskie, cz.1, 1963, [wyd. fotoofset. z: Lud... Serya XX..., 1887].

K 21 Rad - T.21Radomskie, cz. 2, 1964, [wyd. fotoofset. z: Lud... Serya XXI..., 1888].

K 22 Łęcz - T. 22 Łęczyckie, 1964, [wyd. fotoofset. z: Lud... Serya XXII..., 1889].

K 25 Maz - T. 25 Mazowsze, cz. 2, 1963, [wyd. fotoofset. z: Mazowsze. Obraz..., t. 2 Mazowsze polne, 1886].

K 26 Maz - T. 26 Mazowsze, cz. 3, 1963, [wyd. fotoofset. z: Mazowsze. Obraz..., t. 3 Mazowsze leśne, 1887].

K 27 Maz - T. 27 Mazowsze, cz. 4, 1964, [wyd. fotoofset. z: Mazowsze. Obraz..., t. 4 Mazowsze stare. Mazury. Kurpie, 1888].

K 28 Maz - T. 28 Mazowsze, cz. 5, 1964, [wyd. fotoofset. z: Mazowsze. Obraz...,t. 5 Mazowsze stare. Mazury. Podlasie, 1890].

K 39 Pom - T. 39 Pomorze oraz Aleksander Hilferding, Ostatki Słowian na południowym brzegu Bałtyckiego Morza, przeł. Oskar Kolberg, z rękopisów oprac. Jerzy Kądzioła, Danuta Pawlakowa, red. Józef Burszta, 1965.

K 40 MazP - T. 40 Mazury Pruskie, z rękopisów oprac. Władysław Ogrodziński, Danuta Pawlak, red. Danuta Pawlak, 1966.

K 50 Sa-Kr - T. 50 Sanockie-Krośnieńskie, cz. 2, z rękopisów oprac. Bogusław Linette, Tadeusz Skulina, red. Agata Skrukwa, 1972.

Kot Zn - Kotula Franciszek, Znaki przeszłości. Odchodzące ślady zatrzymać w pamięci, Warszawa 1976.

Kul Rop - Nad rzeką Ropą. Zarys kultury ludowej powiatu gorlickiego, red. Roman Reinfuss, Kraków 1965.

Kul Wiel - Kultura ludowa Wielkopolski, red. Józef Burszta, Poznań, t. 1 1960, t. 2 1964, t. 3 1967.

Kutrz Kurp - Kurpie Puszcza Zielona, red. Anna Kutrzeba-Pojnarowa, Wrocław, t. 1 1962, t. 2 1964, t. 31965.

ŁSE

MAAE

- , Łódzkie Studia Etnograficzne”, Wydawnictwo Polskiego Towarzystwa Ludoznawczego, Łódź-Warszawa, R. 5 1963, R. 22 wyd. w 1983 za r. 1980.

- „Materiały Antropologiczno-Archeologiczne i Etnograficzne wydawane staraniem Komisji Antropologicznej Akademii Umiejętności w Krakowie”, Kraków, t. 101908 , t. 111910. 
Mar Drzew - Marczewska Marzena, Drzewa w języku i kulturze, Kielce 2001.

Mat NTarg - Matyas Karol, Świat i przyroda w wyobraźni chłopa (ze wsi Zabrzezie pow. nowotarski i z Zawody pow. nowosądecki), Lwów 1888.

Mif Tok - Mify narodov mira. Enciklopedija, red. Sergej A. Tokarev, t. 1, Moskva 1980.

NKPP

- Nowa księga przysłów i wyrażeń przysłowiowych polskich, w oparciu o dzieło Samuela Adalberga opracował Zespól Redakcyjny pod kierunkiem Juliana Krzyżanowskiego, Warszawa, t. 1 1969, t. 2 1970, t. 3 1972, t. 41978.

Nieb Przes - Niebrzegowska Stanisława, Przestrach od przestrachu, Lublin 2000.

PSL - „Polska Sztuka Ludowa”, Warszawa, R. 17 1963, R. 441990.

Plesz Międz ～- Pleszczyński Adolf, Bojarzy międzyrzeccy. Studium etnograficzne, Warszawa 1892.

Płat Krak - Albośmy to jacy tacy. Zbiór pieśni Krakowiaków wschodnich i zachodnich, zebrał i oprac. Piotr Płatek, Kraków 1976.

Stoin Żyw - Pieśni żywieckie, zebrał Stefan M. Stoiński, Kraków 1964.

Stom Antr - Stomma Ludwik, Antropologia kultury wsi polskiej XIX w., Warszawa 1986.

Tom Drz - - Tomicka Joanna, Tomicki Ryszard, Drzewo życia. Ludowa wizja świata i człowieka, Warszawa 1975.

Udz Biec - Ziemia biecka. Lud polski w powiatach gorlickim i grzybowskim, red. Udziela Seweryn, Nowy Sącz 1994.

Wisła $\quad-$,Wisła. Miesięcznik geograficzno-etnograficzny”, Warszawa, t. 2 1888, t. 3 1889, t. 6 1892, t. 7 1893, t. 10 1896, t. 12 1898, t. 17 1903, t. 181904.

Wit Baj ～- Witkoś Stanisław, Bajdy i Moderówka, Poznań 1977.

Ziół Gaw - Ziółkowska Maria, Gawędy o drzewach, Warszawa 1988.

Zow Bib - Zowczak Magdalena, Biblia ludowa. Interpretacje wątków biblijnych w kulturze ludowej, Wrocław 2000.

ZWAK - „Zbiór Wiadomości do Antropologii Krajowej” wydawany staraniem Komisji Antropologicznej Akademii Umiejętności, Kraków t. 6 1882, t. 7 1883, t. 8 1884, t. 91885 , t. 101886 , t. 161892.

\section{Summary:}

The article discusses the symbolism of the hazel plant which constitute a segment (one facet) of the cognitive definition of a hazel bush. The symbolism of the hazel is a category which terminate and gather in together other facets constituting the entry 'Hezel' in the Lublin ethnolinguistics dictionary (Słownik stereotypów i symboli ludowych, red. J. Bartmiński, S. Niebrzegowska-Bartmińska): i.e. the plants' provenance, image, time and place of flourishing; its magical, apotropaical, therapeutical, ritual and practical use etc. The symbol is thus - next to the stereotype - the second key concept in this dictionary. The author shows the different symbolic meanings attributed to hazel in Polish folk culture - the symbolism of the space tree, the symbolism of sacredness, a symbol of life, duration, recovery and growth; symbol of power and health, the symbolism of fertility and abundance, and a symbol of girl.

\section{Keywords:}

ethnolinguistics, symbol, cognitive definition, hazel, folk culture 
Olga Kielak $\quad$ Symbolika leszczyny w polskiej kulturze ludowej. Fragment definicji kognitywnej...

\section{Streszczenie:}

W artykule omówiona została symbolika leszczyny stanowiąca wycinek (jedną fasetę) definicji kognitywnej leszczynowego krzewu. Symbolika leszczyny jest kategorią, która wieńczy hasło, bazując na pozostałych fasetach - dotyczących m. in. pochodzenia, wyglądu, czasu i miejsca kwitnienia, zastosowania apotropeicznego, magicznego, leczniczego, obrzędowego i praktycznego - spina je wspólną klamrą. Symbol jest bowiem, obok stereotypu, drugim kluczowym pojęciem w lubelskim słowniku etnolingwistycznym (Słownik stereotypów i symboli ludowych, red. J. Bartmiński, S. Niebrzegowska-Bartmińska). Autorka prezentuje różne sensy symboliczne przypisywane w polskiej kulturze ludowej leszczynie - symbolikę drzewa kosmicznego; symbolikę świętości; symbol życia, trwania, regeneracji i wzrastania; symbol mocy i zdrowia, symbolikę płodności i obfitości oraz symbol dziewczyny.

\section{Słowa kluczowe:}

etnolingwistyka, symbol, definicja kognitywna, leszczyna, kultura ludowa 